\title{
Effect of various salinity levels on growth and development of Chenopodium album plant
}

Sajjad Ali ${ }^{1 *}$, Sami Ullah ${ }^{2}$, Sher Wali ${ }^{3}$, Kashif $\mathrm{Ali}^{3}$ and Muhammad Hashim Khan ${ }^{3}$

1. Department of Botany, Bacha Khan University Charsadda, KPK-Pakistan

2. Centre of Plant Biodiversity, University of Peshawar-Pakistan

3. Department of Botany, Islamia College University Peshawar, KPK-Pakistan

*Corresponding author's email: $\underline{\text { Sajjad_ali00@yahoo.com }}$

Citation

Sajjad Ali, Sami Ullah, Sher Wali, Kashif Ali and Muhammad Hashim Khan. Effect of various salinity levels on growth and development of Chenopodium album plant. Pure and Applied Biology. Vol. 5, Issue 4, pp1019-1025. http://dx.doi.org/10.19045/bspab.2016.50127

\begin{tabular}{llll}
\hline \hline Received: 23/07/2016 & Revised: 06/09/2016 & Accepted: 10/09/2016 & Online First: 15/09/2016 \\
\hline
\end{tabular}

Abstract

The present study shows the ionic and osmotic relation in Chenopodium album by the keeping the plant in different salinity levels i-e in six salinity levels $(0-250 \mathrm{~mm} \mathrm{NaCl}$ range) for 60 days. The stress of salt was provided earlier to the soil, before the seed were potted by the help of water which were used for irrigation. The growth and development of plants were occurred between $110 \mathrm{~mm}$ to $150 \mathrm{~mm} \mathrm{NaCl}$. The plants possess a very strong and precise system to become stable osmotically against sudden and abrupt increase in $\mathrm{NaCl}$ stress. It was investigated that up to $88 \%$ of osmotic stability was in mature leaves which were achieved due to accumulation of inorganic ions $\left(\mathrm{Na}^{+}, \mathrm{K}^{+}\right.$, and $\left.\mathrm{Cl}^{-}\right)$. At the provide $\mathrm{NaCl}$ concentration. The compound which affects the osmosis was also very low. By providing all the salinity treatments from $(0-250 \mathrm{~mm})$ the mature leaves have more concentration of $\mathrm{Na}^{+}$and low concentration of $\mathrm{K}^{+}$, while the higher $\mathrm{K}^{+}$and low $\mathrm{Na}^{+}$were found in young leaves. Another application of shoot sap consists of $\mathrm{K}^{+}$progressively increases with increase the concentration of the salt in mature leaves. A very efficient relation between $\mathrm{NaCl}$ change $\mathrm{H}^{+}$and $\mathrm{K}^{+}$concentration were observed in the root of such particular plants. This report clear the work and character of inorganic ion for osmotic stability in salt loving plant, and also make the mechanism clear of $\mathrm{Na}^{+}$in vacuole, and also their uptake movement in shoots.

Keywords: Salinity; Chenopodium album; Ionic concentration

\section{Introduction}

The world facing many problems like global warming, Pollution of water and atmosphere, but the salinity is also one of the important issues which affect the growth of crop production in entire world. [1, 2] to remove this problem or solve the problem of salinity a billion of dollars were utilized but cannot be solved. Also many practices were done such as land improving, plantation of crop especially salt tolerant crops, able to perish the huge amount of salt from the soil and lower the water table at same time. It is very important to agriculture engineering for making a precise and easier method to understand the underlying physiological 
process of plants. The stresses such as abiotic stress which are lethal for many plants, the Chenopodium album show an a awesome tolerance against all the abiotic stress i-e frost, salinity and drought [3] some species of Chenopodium have the remarkable ability to grow in different concentration exactly like those which is found in the saline water [4]. The application of these plants, especially the physiological function show promice in the abiotic stress tolerance is still unknown. But the special interest from Botanist and agronomist and all those scientist who are directly related to the plants [5-7] it's clear indicate that this tolerance are still unknown. [8] have given a possible reason, that change in temperature make change on enzyme function including in carbohydrate partitioning in salt acclimated and salt stress cotyledons of Chenopodium immature plants. All these observed note the variation in a cotyledon source sink relation in these plants which treated with in the presence of requirements to provide soluble sugars and proline [9] show that when these plants were in immature stage, their adaptation is very high and awesome to soil salinity is due to improved metabolic control related to ionic absorption, and also the proper adjustment of osmosis.

The main purpose of this investigation was to identify the features of ions especially the inorganic for their proper adjustment of osmosis in this plant and also the close relation of $\mathrm{K}^{+}$in roots, vacuolar $\mathrm{Na}^{+}$ sequestration and also include the movement and their transport to the shoot in saline soil.

\section{Materials and methods}

\section{Condition of growth and plant material}

The seed were cultivated in the glass house of Agriculture University Peshawar during October 2013 and May 2014. Their growth were occur in the glass house in 8.02 black plastic pots, each pot have two plants and the plants were introduced in a standard potting mix ( $53 \%$ of composed pink bark,
$16 \%$ corase sand, $8 \%$ sphagnum peat was used. The growth of plants was occurred under ambient light, in a glass house at controlled temperature between $17 \mathrm{C}^{\circ}$ and $22 \mathrm{C}^{\circ}$ and also under a controlled humidity at $\sim 58 \%$ at the University of Agriculture Peshawar, Pakistan.

\section{Agronomic assessment and the treatment of salinity}

Two different and accurate ways were introduce to deliver salinity stress. The method 1 includes the salt which were calculated and added in the pot before the seed were planted. The $\mathrm{NaCl}$ which were added into the pot their amount were ranged from $1.6 \mathrm{gl}^{-1}$ to $9.2 \mathrm{gl}^{-1}$ to make a desirable variation of $\mathrm{NaCl}$ concentration. The water was given to plant on daily basis in a way that ensured that no leaching occurred from the pots by watering the pots. To make it more accurate a plate was placed and the main purpose of these plate was that to retain the prevent the leaching and others nutrients. By making the situation accurate and controlled the seed were expressed to salinity stress from the very starting days of their imbibition that was the $1^{\text {st }}$ method which were introduced.

In another phase of experiment another method, method 2 were introduced the germination of seedling were occurred under controlled condition having no salt until 13 $\mathrm{d}$ old, and the treatment of $\mathrm{NaCl}$ were given in $35 \mathrm{mmd}^{-1}$ inooments till the desirable concentration was reached. The growth of plant which were occurred in that pot which were of limited size a small amount of $\mathrm{NaCl}$ was removed from the pot by transpiration and transported to shoot( Method 1 ) due to both of these process gradual decline of soil salinity occurred. But the stress of $\mathrm{NaCl}$ was still substantial and the variation would be very less during the initial stage of the experiment. The period of the stress treatment in the experiment was $60 \mathrm{~d}$, when the duration was complete then the plant 
was removed from the pots where they are planted. After given the treatment and also after the removal the measurement of their shoots, length of root, and their biomass, appropriate leaf sample were collected for analysis.

Measurement of chlorophyll fluorescence The highest photochemical efficiency of photosystem II (PSII chlorophyll fluorescence $F_{v} / F m$ ratio) their measurement occurred in dark adapted album leaves. The sample of the young leaves and matured leaves were collected, then wrapped by aluminum foil, after collecting and wrapping they were frozen at $-20 \mathrm{c}^{\circ}$. when the frozen sample were melted then extract all the sap as described in [10]. The sample which was collected mixed thoroughly, diluted by a factor of 40. And with the help of flame photometry its $\mathrm{Na}^{+}$and $\mathrm{K}^{+}$concentration were measured.

\section{Measurement of sap osmolality}

As the above description tells that how the sap extract were obtained from the C. album leaf and then measure by using vapour pressure mometer.

\section{Determination of seed germination}

The seeds of Chenopodium album were taken and place in petri dishes on filter paper which were wet at $21+-11 \mathrm{C}^{0}$ in dark for 5 days. The seed which were placed in petri dishes for germination to six different categories of osmotic ion. The $\mathrm{NaCl}$ and polyethylene slycole (PEG). The germination of the seed was tested by five different salt concentration $(50,100,150$, $200,250 \mathrm{~mm}$ ) and the given treatment were compared with controlled (distilled water). Another phase of the seed germination were the introducing of non-ionic solution isotonic to above concentration using ether methanol or PEG 500, for making the experiment precise and accurate each treatment were replicated 5 time with 20 seeds which were germinated the number of these seed were counted every day and the germination test lasted $50 \mathrm{~d}$.

\section{Results}

Role of photosynthesis and responses of germination and growth

C. album is a halophyte and its response to the treatment of salinity was also variable because of its halophyte characters as shown in (Table $1 \& 2$ ). The plant which maximum growth was achieved by the plant which were treated the lowest concentration of $\mathrm{NaCl}$ in present experiment i-e $\mathrm{NaCl}$ concentration of $50 \mathrm{~mm}$. The biomass of the shoot were also high at $50 \mathrm{~mm} \mathrm{NaCl}$ treatment to both cases; at sever treatment $(250 \mathrm{~mm})$ which were roughly equal to sea water cause a related minor $(\sim 18 \%)$ and the fresh weight of the shoot reduced. The most notable situation were the severe effect of $\mathrm{NaCl}$ on the length of shoot, with a nearly $65 \%$ reduction observed under the maximum treatment $(250 \mathrm{~mm})$ but in such severe condition the plant were still have the ability to produce viable seeds. An important and characteristic effect of salt stress on the germination of seed was obvious only for concentration > 200mm (Table $1 \& 2$ ). The comparisons between both the solution, the isotonic $\mathrm{NaCl}$ and Manito or PEG solutions show specific ionic toxicity is the main reason for the notable decline in seed germination. Indeed at the highest level $(250 \mathrm{~mm} \mathrm{NaCl}$ : equivalent to $0.75 \mathrm{osmkg}^{-1}$ ). 
Table 1. The ratio of sodium to Potassium. In mature and young leave of Chenopodium plant grown at different external $\mathrm{NaCl}$ level (that is calculated from the original data shown in table)

\begin{tabular}{|c|c|c|c|}
\hline External NaCl $(\mathbf{m m})$ & Old leaves & Young leaves & Mature/ young\% \\
\hline 0 & 13.9 & 440 & 4517 \\
\hline 50 & 0.4 & 10.1 & 3512 \\
\hline 100 & 0.5 & 3.2 & 321 \\
\hline 150 & 0.9 & 1.6 & 171 \\
\hline 200 & 1.00 & 1.9 & 163 \\
\hline 250 & 1.01 & 2.0 & 258 \\
\hline
\end{tabular}

Table 2. The Contribution of $\mathrm{Na}^{+}$and $\mathrm{K}^{+}$at different level of salinity in growing leave of Chenopodium

\begin{tabular}{|c|c|c|c|c|c|c|}
\hline $\begin{array}{c}\text { NaCl } \\
(\mathbf{m m})\end{array}$ & \multicolumn{3}{|c|}{ Mature Leaves } & \multicolumn{3}{c|}{ Young Leaves } \\
\hline & $\begin{array}{c}\text { K+Na } \\
(\mathbf{m o s m})\end{array}$ & $\begin{array}{c}\text { Measured } \\
(\mathbf{m o s m})\end{array}$ & Measured\% & $\begin{array}{c}\text { K+Na } \\
(\mathbf{m o s m})\end{array}$ & Measured (mosm) & Measured\% \\
\hline 50 & 143 & 180 & 60 & 445 & 485 & 69 \\
\hline 100 & 329 & 345 & 95 & 460 & 575 & 70 \\
\hline 150 & 465 & 485 & 110 & 495 & 595 & 85 \\
\hline 200 & 630 & 710 & 115 & 545 & 622 & 105 \\
\hline 250 & 755 & 825 & 118 & 760 & 870 & 115 \\
\hline
\end{tabular}

\section{Relation of ion and osmosis in shoot}

A clear variation was present between sap $\mathrm{K}^{+}$and $\mathrm{Na}^{+}$Concentration were there in the whole range of salinity treatment during experiment, this variation were clear indicated in young and in old leaves. As usual an increase in external concentration of $\mathrm{NaCl}$ level a noticeable increase in the amount of $\mathrm{NaCl}$ in leaves of plants.

The agronomics feature of the $\mathrm{C}$. album plants grow at various salinity levels. As earlier two method were introduces, in method 1 the salt were premixed with the soil before it planted (A) represent the root and shoot length (B) root and shoot fresh weight. The percentage of the seed of Chenopodium album which were germinated their \% after 6 days of treatment with different concentration of $\mathrm{NaCl}$ caused a noticeable variation in the amount of $\mathrm{Na}^{+}$ deposited in plant leaves.

The Contents of ions which is in the shoot sap form both the mature and young leaves from various plant grown at different $\mathrm{NaCl}$ Level.

\section{Discussion}

Toxicity of specific ion and osmotolerance

The common and important of separating the sodium toxicity which cause serious damage and osmotic stress has been repeatedly stress by many views [11]. There is also an important elue in the literature as to what situation is related to be more natural to plants, being exposed to drastically salt stress ( $\mathrm{NaCl}$ up- Shock) or to have increased the salinity level incrementally.

In many cases, the raising of water tables cause salinity to which we are concern and in the root zone the concentration of salinity build up is to be a very slow process. Literature gives us a transparent view that a large number of researchers have adopted this approach in which slowly increases occur in their studies $[10,11]$. Under many situations it may be correct and true that 
seeds of many native plants are gifted by their inheritance to grow and germinate in height stress soil condition of salt. By the light of these observation and solid evidence the researcher and breeders deliver direct seed cultivated into saline media. The result reported here show that, in the case of the Chenopodium, the grow response of the plant is not much different to these two variable way of applying the salt stress. The optimal biomass and the plant growth were achieved at $\mathrm{NaCl}$ level ranging from $50 \mathrm{~mm}$ to $100 \mathrm{~mm} \mathrm{NaCl}$. Hence, the Chenopodium plant shows a class act of very awesome and efficient system against abrupt $\mathrm{NaCl}$ stress. According to [11], the osmotic and ionic component is of salt stress is differ significance, with the osmotic components dominating over the $1^{\text {st }}$ several weeks. The seed germination of the Chenopodium plant is more determental to $\mathrm{Na}$ or other toxicity as compared with the osmotic components of salt stress. The survival ability of Chenopodium plant was explained by the proneness of significant gradient in the distribution of toxic stress $(\mathrm{Na}$ and $\mathrm{Cl})$ and non-toxic essential ( $\mathrm{S}, \mathrm{K}, \mathrm{Mg}, \mathrm{Ca}, \mathrm{P}$ ) element over the seed coat of salt-treated plants also in the embryo [12]. Hence, it may be thought that, if the germinated seed fail to exclude the toxic $\mathrm{Na}^{+}$from embryo unavailable. Osmolyle Contribution and osmotic settlement providing the huge energy cost organic osmolyles [13]. It is more important for plant to utilize sodium as available osmoticum for the osmotic settlement, assuming it does not create problem and not interfere with cell metabolism. This appears to be in the case of Chenopodium. The experiment show that high percentage of cell osmotic started in mature leaves about $85 \%$ and between $73 \%$ - $100 \%$. Started in young leaves may be adjusted by mean of deposition of $\mathrm{K}^{+}$and sodium $\left(\mathrm{Na}^{+}\right)$(Table 2$)$. The remaining may be attributed to chloride. While the real $\mathrm{Cl}^{-}$ in sap sample of Quinoa plant leaf was not measured in this experiment, it is usually explain and observed that it concentration is $\sim 1.4$ time that for sodium see [14]. This fair enough to add the some percentage points needed for complete osmotic adjustment. So the inorganic osmolyte would help in the adjustment of osmosis both in mature and young leaves only.

The organic and inorganic osmolyte role is still highly disputed in the literature. The ability of plant is compatible sloute to accumulate is a frequently mechanism for increasing the yield of crops deliveto stress i-e osmotic stress [15]. The genetic engineer made few attempts to handle the biosynthesis way of that compatible solute which increase the salt tolerance [15, 16]. The stress may responsible for the causing variation in total amount of soluble sugar, proline, starch and other sucrose were listed from the Quinoa [15, 16]. In contrast to these sugar the Glycine beatine and other extract relative to betaine have been identify as a strong osmolyte in entire family member of these plant [17]. However some report also suggested that the level for the certain chemicals i-e Proline and other derviales were appear in very less amount to contribute importantly to cell osmotic adjustment [18]. At the present time the time, the starting set up by inorganic ion has been previously reported in the plants which are rather than saline (glycophytes) [19].

Earlier it was mention that amount of amino acid i-e free amino acid [20] play a vital role in the transport across the membrane, so the setup of cell osmotic indirectly through potassium retention.

The level of $\mathrm{Na}^{+}$and $\mathrm{K}^{+}$were variable in both young and mature leaves, for all treatment of salinity. In young leaves high $\mathrm{K}^{+}$and low level of $\mathrm{Na}^{+}$were present in contrast to old leaves: the result in much higher sap $\mathrm{K} / \mathrm{Na}$ present in young leave (Table 1). 
Young leaves which were under the processing of development, protoceling These leaves from excessive amount of $\mathrm{Na}^{+}$ has been important of $\mathrm{Na}^{+}$ compartmentalization at the entire plant condition in many species [21], [17]. In increase the salinity level (from $50 \mathrm{~mm}$ to $250 \mathrm{~mm}$ ) cause $50 \%$ increase in the contents of mature leaves, this fact give idea about that $\mathrm{Na}^{+}$loading in xylem were very strict or their recreation( removal of salt from plant body) very efficient. These mechanism which were discussed as above determine the salinity tolerance in various species of plant [22] Due to lack of many things like tools, attention and Researcher on such topic in saline plants, it will be amazing to reveal the contribution of these ion movement which are specific to this mechanism in Chenopodium plant.

The other aspect needs more attention. In mature leaves when the salinity increased the $\mathrm{K}^{+}$also increased. But all the given report related to non-saline species, while in contrast to the glycophyte the halophytes are capable to keep constant the $\mathrm{K}^{+}$level or increase with variation in salinity level [2325].

\section{Conclusion}

The results clearly revealed that the Chenopodium album is a halophytes plant and grow at various salinity level. But it shows maximum growth when lowest salts (Nacl) were applied. At $50 \mathrm{~mm}$ the biomass of the shoots were high and give more yields. When the plants were treated with high salts $250 \mathrm{~mm}$ the shoot biomass greatly reduced. The shoot length $65 \%$ reduced. The variation between $\mathrm{K}+$ and $\mathrm{Na}+\mathrm{Concentration}$ in the whole range of salinity treatment during experiments, this variation were clear cut indicated in young and old leaves.

\section{Authors' contributions}

Conceived and designed the experiments: S Ali \& K Ali, Performed the experiments: S
Ali \& K Ali, Analyzed the data: S Wali \& S Ullah, Contributed reagents/ materials/ analysis tools: $\mathrm{MH}$ khan \& S Wali, Wrote the paper: K Ali, S Ullah \& S Ali.

\section{References}

1. Bisson MA \& Kirst GO (1980). Lamprothamnium a euryhaline charophytes. I. osmotic relations and membarane potiential at steady state. Journal of Experimental Botany 31: 1237-1244.

2. Bohnert HJ \& Shen B (1999). Transformation and compatible solutes. Sci Hortic 78: 237-260.

3. Chen TH \& Murata N (2002). Enhancement of tolerance of abiotic stress by metabolic engineering of betaines and other compatible solutes. Curr Opin Plant Biol 5: 250-257.

4. Chin MH, Mason MJ, Xie W, Volinia S, Singer M, Peterson C, Ambartsumyan G, Aimiuwu O, Richter L \& Zhang J (2009). Induced pluripotent stem cells and embryonic stem cells are distinguished by gene expression signatures. Cell Stem Cell 5:111-123.

5. Cuin TA \& Shabala S (2005). Exogenously supplied compatible solutes rapidly ameliorate $\mathrm{NaCl}$-induced potassium efflux from barley roots. Plant Cell Physiol 46: 1924-1933.

6. Flowers TJ \& Colmer TD (2008). Salinity tolerance in halophytes. New Phytologist 179: 945-963.

7. Flowers T \& Yeo A (1995). Breeding for salinity resistance in crop plants: where next? Aust. J Plant Physiol 22: 875-884.

8. Inan G, Zhang H \& Li P (2004). Salt cress. A halophyte and cryophyte Arabidopsis relative model system and its applicability to molecular genetic analyses of growth and development of extremophiles. Plant Physiology 135:1718-1737.

9. Jacbosen SE, Quispe H \& Mujica A (2001). Quinoa: an altrnative crop for saline soils in the andes. CIP Parogram Report 19992000: 403-408. 
10. Jacobsen SE (2003). The worldwide potential for quinoa (Chenopodium quinoa Willd.). Food Rev Intl 19(2): 167-177.

11. Jacobsen SE, Monteros C, Corcuera LJ, Bravo LA, Christiansen JL \& Mujica A (2007). Frost resistance mechanisms in quinoa (Chenopodium quinoa Willd.) European Journal of Agronomy 26: 471-475.

12. Jacobsen SE, Quispe $\mathrm{H} \&$ Mujica A (2001). Scientists and farmer-partners in research for the 21st century. Quinoa: an alternative crop for saline soils in the Andes. CIP Program Report 19992000: 403-408.

13. James RA, Munns R, Caemmerer SV, Trejo C, Miller C \& Condon O (2006). Photosynthetic capacity is related to the cellular and subcellular partitioning of $\mathrm{Na}+, \mathrm{K}+$ and $\mathrm{Cl}-$ in salt affected barley and durum wheat. Plant Cell Environ 29: 2185-2197.

14. Jensen CR, Jacobsen SE, Andersen MN, Nuñez N, Andersen SD, Rasmussen L \& Mogensen VO (2000). Leaf gas exchange and water relations of field quinoa (Chenopodium quinoa Willd.) during soil drying. Europ J Agron 13: 11-25.

15. Koyro HW, Lieth H \& Eisa SS (2008). Salt tolerance of chenopodium quinoa willd., grains of the Andes: Influence of salinity on biomass production, yield, composition of reserves in the seeds, water and solute relations. Tasks for Vegetation Sciences 43: 133-145. http://dx.doi.org/10.1007/978-1-40206720-4_13.

16. Maughan PJ, Bonifacio A, Jellen EN, Stevens MR, Coleman CE, Ricks M, Mason SL, Jarvis DE, Gardunia BW \& Fairbanks DJ (2000). A genetic linkage map of quinoa (Chenopodium quinoa) based on AFLP, RAPD, and SSR markers. Theor App Genet 109:11881195.

17. Munns R (2002). Comparative physiology of salt and water stress. Plant Cell Environ, 25: 239-250.

18. Munns R \& Tester M (2008). Mechanisms of salinity tolerance. Annu Rev Plant Biol 59:651-81.

19. Munns R \& Tester M (2008). Mechanisms of salinity tolerance. Annual Review of Plant Biology 59: 651-681.

20. Munns R (2002). Comparative physiology of salt and water stress. Plant, Cell \& Environment 25(2): 239-250.

21. Munns R \& Tester M (2008). Mechanisms of salinity tolerance. Annu Rev. Plant Biol 59: 651-681. http://dx.doi.org/10.1146/annurev.arplan t.59.032607.092911.

22. Rivelli AR, Lovelli S \& Perniola M (2002). Effect of salinity on gas exchange, water relations and growth of sunflower (Helianthus annuus). Funct Plant Biol 29: 1405-1415.

23. Rosa M, Hilal M, Gonza.'lez JA \& Prado FE (2009). Low-temperature effect on enzyme activities involved in sucrosestarch partitioning in salt-stressed and salt-acclimated cotyledons of quinoa (Chenopodium quinoa Willd.) seedlings. Plant Physiol Biochem 47: 300-307.

24. Ruffino AMC, Rosa M, Hilal M, Gonzalez JA, Prado FE (2010). The role of cotyledon metabolism in the establishment of quinoa (Chenopodium quinoa) seedlings growing under salinity. Plant and Soil 326: 213-224.

25. Trognitz BR (2003). Prospects of breeding quinoa for tolerance to a biotic stress. Food reviews international 19: 129-137. 